\title{
CONTESTABLE DEMOGRAPHIC REASONING REGARDING LABOUR MOBILITY AND MIGRATION
}

\author{
Duška KNEŽEVIĆ HOČEVAR', Sanja CUKUT KRILIĆ"
}

COBISS 1.02

\section{ABSTRACT}

Contestable Demographic Reasoning Regarding Labour Mobility and Migration The essay provides a review of contestable demographic reasoning applied in relation to migration and mobility, in which the notion of the national population as a closed and bounded system still persists. Although free movement of people has been enshrined as one of the fundamental principles of the European Union, their mobility within it remains selective and curtailed in various ways. Drawing on selected studies of labour mobility and migration within the European Union, the authors argue that labour mobility and migration policies continue to categorise people as either more or less entitled to move across the European Union's internal borders. KEY WORDS: labour mobility, labour migration, demographic reasoning, national population, European Union

\section{IZVLEČEK}

\section{Delovna mobilnost in migracije v vprašljivem demografskem umovanju}

Besedilo ponuja pregled vprašljivega demografskega umovanja migracij in mobilnosti, ki še vedno vztraja pri ideji nacionalnega prebivalstva kot zaprtega in zamejenega sistema. Čeprav je svobodno gibanje ljudi med temeljnimi načeli Evropske unije, je njihova mobilnost selektivna in na različne načine omejena. Na podlagi izbranih raziskav delovne mobilnosti in delovnih migracij v Evropski uniji avtorici potrjujeta, da delovne mobilnosti in migracije politike še vedno razporejajo kot bolj ali manj upravičene do gibanja čez meje nacionalnih držav Evropske unije.

KLJUČNE BESEDE: delovna mobilnost, delovne migracije, demografsko umovanje, nacionalno prebivalstvo, Evropska unija

$\mathrm{PhD}$ in Anthropology, Senior Research Fellow, Sociomedical Institute ZRC SAZU, Novi trg 2, SI1000 Ljubljana; duska@zrc-sazu.si

\| PhD in Sociology, Research Fellow, Sociomedical Institute ZRC SAZU, Novi trg 2, SI-1000 Ljubljana; sanja.cukut@zrc-sazu.si 


\section{INTRODUCTION}

The recent concerned and disharmonious responses of European governments to the "refugee crisis" and the extensive migration and mobility in ageing Europe have reinvigorated the persistent appeal of political demographers that it is no longer possible to separate population policies from much wider considerations of the political implications of national identities, nationalisms and international affairs (Teitelbaum, Winter 1998). It seems that political messages are time and again grounded in reiterated demographic dystopias about reproductively more vital foreigners or foreign-born people who are supposedly responsible for the vanishing of the values, way of life, social position and even the culture of the less-reproductive domestic population. Such dystopias address and entrap mobile individuals and labour migrants as well, who as a rule are recognised by official statistics as foreign-born newcomers or as short-term transients, and are not registered in the population count at all.

This article discusses labour mobility and migration within socio-political discourses that address the persistent fear of the "proper composition" of national populations. The article refers to discussions about the perceived threatening compositional change to the "more familiar faces of Europe's nations" (Kligman 2005: 253) brought by the increasing mobility and migration of certain populations within the European Union (EU).

Drawing on a secondary analysis of selected studies on labour mobility within the EU, the authors argue that migration and mobility within the EU borders are still being controlled and managed in ways that categorise mobile people and $\mathrm{mi}$ grants as either more or less legitimate and desirable in their crossing of the EU's internal borders.

In the first part, the article explores the demographic reasoning which refers to "empirically proven" demographic change moving in the direction of a radical transformation of the ethnic composition of Western Europe by below-replacement fertility and the emigration of the domestic population on the one hand, and the increasing immigration of people of various ethnic and racial backgrounds on the other. This issue is further discussed by presenting attempts to study the political consequences of such population dynamics in order to (dis)prove such concerns. To better understand such demographic dystopias, the authors look at the central concept of demography - the (national) population, and the history of its imagining.

In the second part, the practices and explanations of demographic processes are discussed through selected examples of labour mobility within the EU. Confronting the ideology of free movement across the EU's internal borders, the authors discuss the legitimacy of different categories of mobile individuals, and how it is understood by policymakers and the public. In the final part of the article, the reader will learn whether mobile individuals are valued through the notions of an open or closed system of national population. 


\section{CONTESTABLE DEMOGRAPHIC REASONING}

\section{Fear of a "Transformed Composition" of the Population}

In 2013, a workshop entitled "Population: The Long View" was held at St. John's College in Oxford in order to discuss current, large-scale and long-term interdisciplinary population issues. The editors of the 2015 special issue of the journal Population Studies, David Coleman, Stuart Basten and Francesco C. Billari (Coleman et al. 2015), all well-recognized demographers, believed that recent demographic research had mostly focused on micro-level population analyses despite the impression that media and politics were dedicating more attention to macro-level population changes. These include unfavourable ratios between population and resources, rapid population growth in poorer countries and population ageing in richer ones, population decline in some countries and large-scale international migration in others, and population movements due to climate change.

The editors regretted that the invited authors did not pay more attention to the issue of migration (ibid.: S7). However, the reason for this might lie in a very sensitive discussion of the long-term consequences of population processes in Western Europe commenced by one of the editors, David Coleman, a decade ago (2006). In his article Immigration and Ethnic Change in Low-Fertility Countries: A Third Demographic Transition (2006), Coleman argued that in the last five decades in some industrial countries, ${ }^{1}$ there was evidence for and empirical proof of altered ethnic composition through persistent below-replacement fertility of domestic populations, high levels of immigrants of remote geographical origins or with different ethnic and racial ancestry, and increasing emigration of domestic populations. According to Coleman, such demographic change - a precursor of a third demographic transition towards a radically transformed ethnic composition of Western Europe - should raise anxiety about several potential political consequences which had been de-emphasized by social science until now. Critical of the prevailing asymmetrical discussions, which as a rule highlighted the human rights of immigrants only, while labelling domestic protests against them racist and xenophobic, Coleman (2006: 427) strove for a "more balanced" debate without excluding those who warned against long-term consequences of the transformed and changing ethnic composition of European populations.

Coleman's concern about the under-communicated political and social implications of the current demographic changes can be recognised in the works of the forerunners of political demography as a research field. Myron Weiner, the founder of the concept of political demography, warned against "difficult dimensions" of migration already in the early 1970s. Conducting fieldwork in selected places in India

1 Coleman's calculations and population projections were applied to the USA and seven European countries: Austria, Germany, Denmark, the Netherlands, Norway, Sweden and the UK. 
on the costs and benefits of migration for the local inhabitants, he pointed out the dilemma: "How to find a way in which local people belonging to one ethnic community could obtain greater equality in the employment market without at the same time restricting the opportunities of migrants and their descendants belonging to other ethnic groups [...]" (Weiner in Weiner, Teitelbaum 2001: vi).

Until his death in the late 1990s, Weiner devoted his career to investigating the political implications of large-scale population changes, i.e. issues that should be addressed by political demography. The newly proposed field of study referred mainly to the active responses of governments, their policies and the public to population change brought by fertility, mortality and (labour) migration. Yet this subject, that addressed so explicitly the relationship between politics and demography, did not attract the interest of political scientists even three decades after Weiner had defined the research area. Weiner ascribed this neglect to their poor knowledge of demographic theory, methods, and concepts, or their general viewpoint that demography was largely an atheoretical discipline, focused on the measurement of population size, composition and territorial distribution and detailed studies on fertility, mortality and territorial movement (ibid.).

Even now, when political scientists have finally recognised political demography as a significant research field ${ }^{2}$ Jack A. Goldstone explained that political scientists were uninterested in demography probably because demography evolved as a highly specialized and technical field of knowledge, requiring advanced mathematics and the analysis of enormous amounts of data necessary for studies of demographic change. The author believed that mutual collaboration between the two disciplines was inevitable since demographers usually cannot explain how people and social institutions would react to demographic changes (Goldstone 2012).

\section{Ignorance of the History of Population Theory}

If demographers and political scientists, in their common project, strive for a mutually informed discipline of political demography in order to avoid misunderstanding the political implications of population change, it is necessary to look into the history of demography as a science (Demeny 1988; Hodgson 1991; Kreager 1993, 1997, 2008, 2009, 2015; Szreter 1993; Kertzer, Fricke 1997; Melegh 2006) in order to make it easier to understand the current demographic dystopias which usually serve as a guide for population policymakers. For instance, Coleman's concern about the changed composition of Western Europe can be more easily understood if we draw on the history of imagining the national population - the basic concept of contemporary demography. In his article Population Theory - A Long View (2015), Philip Kreager

2 The authors refer to the recently published collection of essays entitled Political Demography: How Population Changes Are Reshaping International Security and National Politics (2012). 
re-emphasized ${ }^{3}$ that demography had been in service of the state since the eighteenth century when the notion of population was defined anew. Contrary to ancient European empires and states of diverse aristocratic elites, in which the ethnic or religious affiliation of the population was secondary to the people's loyalty and productivity, the newly defined (national) population consisted of people with a common linguistic, cultural, and historical background, with associated material conditions such as residence in a common territory and shared descent. Compared to theories of government in ancient regimes, which put forward a mechanism of maintaining a balance and peace between sub-populations, modern nation-states became gradually seen as responsible for counting "all" the people with national statistical offices. The general idea of the population in ancient and early modern states did not address all the people as full citizens, but only a minority - usually adult male property-owners who belonged to various competing clans or factions (Kreager 2015).

An important novelty of the newly-defined population was the idea that population was not only a historical and cultural phenomenon but a natural one as well. Imagined organic ties to people's territory and environment were considered as people's natural rights to such places, and such "natural wholes" had to be "home-produced" (Kreager 1997: 156). Population was viewed as a closed-bounded system: a state boundary cut a population off from other populations across a boundary, and the boundary introduced an epistemological closure as a precondition for the demographic ideal of complete enumeration and records of its membership (ibid.).

This type of static understanding of a national population still underlies demographic reasoning about the population composition, including Coleman's reflection on the third demographic transition. Yet drawing on human agency - the perspective that explains individuals' creative and contestable management of collective identities and their making - the line of reasoning which understands a population as a homogenous unit of passive carriers of culture, can be at least questioned. Therefore, Kreager insisted that questions of how a population was defined for demographic research, and how collective identities were defined in a classificatory and mensurational exercise, should be central in applied demography, because such questions predetermined demographic reasoning about the composition of an observed population. Or, as Kreager himself puts it:

The fact that people may report their ethnic, religious, and other identities differently from one census to the next and may tailor birth, marital, occupational, and migration histories to suit currently preferred statuses, is significant not only as a potential source of bias affecting the analysis of trends but as evidence of the active adjustment of population composition and structure to changing circumstances. (Kreager 1997: 148)

3 Kreager has explained the idea of the national population in detail in previously published works; see e.g. Kreager 1997. 
Finally, in demography it is common to view fertility, mortality and migration as constituents of the structure and composition of the observed population. Yet collecting data on migration compared to births and deaths has proved to be more demanding, since migration movements have only recently been introduced into the historical model of explanation of the first demographic transition (Van de Kaa 1999). ${ }^{4}$

Bringing migration into both explanatory models of historical demographic transitions, from high fertility and mortality rates to low levels, Van de Kaa showed that in the period of the first demographic transition, when the European populations were increasingly settling in "new worlds", Europe was predominantly an emigration region. ${ }^{5}$ Van de Kaa (2002) also believed that migration in Europe played a significant role between and after the two world wars, and when European countries were faced with massive movements of refugees and displaced persons, returning prisoners and others, when Europe experienced a temporary "revenge of history" during the de-colonization process. Moreover, he attributed a real shift of migration, this time as more permanent immigration to Europe, to the introduction of guest-worker programmes in the 1960s, when the governments of Western and Northern Europe tried to solve shortages of unskilled labour.

Yet the considerable immigration of guest workers in the 1960s and 1970s, emigration from Central and Eastern Europe after the fall of the Berlin Wall, and political asylum seekers from all over the world in the early 1990s, coincided with the recorded below-replacement fertility levels in European countries. Based on calculations showing that during the second demographic transition between 1965 and 1999 the majority of Western and Northern European countries registered population growth due to immigration, Van de Kaa (1999) assumed that Europe would turn from an emigrant to an immigrant region. He further believed that in the case of a temporary period of below-replacement fertility and continuing immigration, Europe would as so many times in the past adapt and act as an immigration area with a carefully controlled influx, while in the case of a lengthy period of below-replacement fertility and rapid ageing of the population it was immigration that would shape the demographic future of Europe. Yet Van de Kaa did not refer to just any kind of immigration. He explicitly advocated selected immigration if the immigrants were seen as a solution to the failed European self-reproduction: "Longterm considerations lead to the conclusion that the quality of immigrants and their willingness and ability to integrate are important for the viability and continuity of European civilization" (ibid.: 40).

4 In demography, the "first demographic transition" is used synonymously for so-called modern demographic behaviour denoted in the historical record as voluntarily limited marital fertility.

5 If demographers identified the first demographic transition through the available statistical evidence in the period of the radical fertility drop between 1850 and 1950 in nearly 700 European provinces (Friedlander et al. 1999), Van de Kaa set the start of the second demographic transition in 1965, when the majority of European countries first registered persistent sub-replacement fertility (Van de Kaa 1987). 


\section{LABOUR MOBILITY AND MIGRATION BETWEEN IDEAS OF OPEN AND CLOSED POPULATION SYSTEMS}

\section{Limits to the Freedom of Movement Principle}

There is a discrepancy between the actual practices of the migrant-receiving countries that are more in line with the above presented idea of the national population as a closed system, and the idea of free movement of people enshrined in founding documents of the EU, such as the Treaty on the Functioning of the European Union. For instance, freedom of movement beyond the boundaries of national populations, introduced as one of the EU's fundamental freedoms, has been recognised in the Single European Act as a necessary element for the creation of the European common market (Kmak 2015). In its 2013 Communication on Free Movement, the European Commission announced that

the free movement of workers has positive effects on economies and labour markets. The four fundamental freedoms, which are inextricably linked, create the conditions for more efficient allocation of resources within the EU. Free movement of EU citizens stimulates economic growth by enabling people to travel, study and work across borders and by allowing employers to recruit from a larger talent pool. In view of the significant imbalances in Europe's labour markets and its declining working-age population, labour mobility contributes to addressing skills and job mismatches. (European Commission 2013: 2)

The recent lifting of obstacles for citizens of the EU Member States to seek employment in another EU country notwithstanding, citizens still face numerous difficulties when moving between different EU countries. It is generally agreed that the EU needs to further develop its policies to exploit its "mobility potential" (CEPS 2014). Yet labour mobility within the EU is still a limited phenomenon. According to the European Foundation for the Improvement of Living and Working Conditions, Europeans are not very much in favour of looking for a job abroad (Eurofound 2014). Van Houtum and Van Der Welde (2004) described this trend as "immobility" of the labour force, observing an overestimation of the potential mobility of the labour force in most studies on the issue.

Particularly in the last decade, there have been extensive discussions about the limits of the freedom of movement principle. Referring to increasing controls and management of mobility/migration, Favell (2008: 705) talked about a "new European migration system". Moreover, after the most recent enlargements of the EU (in 2004, 2007 and lastly in 2013), most of the "old" Member States have striven to counteract the expected "invasion" of the cheaper labour force from the "new" European Member States by imposing several transitional restrictions to entry to the labour 
market in the forms of quotas and work permits. Despite attempts to facilitate the freedom of labour and movement in the internal EU market, Pijpers (2009) assessed the labour market entry policies in the "old" member states as largely restrictive in the first years after the enlargement. Needless to say, specialised labour market intermediaries, subcontractors and legal advisory firms profited from the transitional border closing through the application of all kinds of circumvention strategies in order to recruit scarce low-skilled labour from the new Member States (Pijpers 2007).

Similar recent examples of violation of labour legislation on posted work have demonstrated that the lifting of transitional restrictions in labour market access to citizens of new EU Member States has not resulted in a cessation of such violations. To illustrate, although

the posting of workers in principle contributes to balancing the demand and supply of services in the EU and provides valuable economic opportunities for companies and workers, it also exposes the deeply rooted tensions between promoting the free movement of goods, capital, services and labour on the one hand, and maintaining the European social model and established industrial relations, including industrial action to protect collective interests, on the other. (Vah Jevšnik, Rogelja 2018: 24)

While freedom of movement remains one of the most celebrated, practical and visible rights of the EU integration, as it also decreases the gaps and mismatches between skills and needs of the labour market in ageing societies and thus reduces sectoral labour shortages, limits remain to the implementation of this principle throughout the EU and to the exercise of the associated social rights. Despite the proclaimed common ideology of economic integration at the EU level, the Member States insist on keeping their respective welfare state systems under their own control (Barslund, Busse 2016).

\section{Labour Mobility and Social Rights}

The "discretionary power" of the nation-states can also be seen in the granting of social rights to mobile individuals. Ciupijus (2011) argued that the processes of European integration could provide grounds for a more denationalised notion of citizenship, the so-called European citizenship. In practice, however, the Member States still make the right to residence conditional on active employment or the citizens' possession of medical insurance in their respective countries. Moreover, the social rights afforded to mobile EU citizens are generally lower compared those afforded to citizens (Ciupijus 2011; Lafleur, Mescoli 2018). 
At the policy level, the Citizenship Directive ${ }^{6}$ has explicitly limited the mobility rights of EU citizens who have resided in an EU resident state for less than five years. Lafleur and Mescoli (2018: 483) even observed that workers, former workers who actively sought employment and persons who were not economically self-sufficient could lose their right of residence if they became an "unreasonable burden on the social system" of the host country.

It seems that arguments in favour of increased mobility were to a certain extent overshadowed by a general fear among the populations of most of the "old" Member States that too many workers from Eastern Europe were moving to the West primarily in search of generous welfare benefits (Ciupijus 2011; Roberts 2015; Lafleur, Mescoli 2018). The assumption behind such fears was that some categories of immigrants/mobile citizens were abusing the welfare system of the "host" societies to a higher degree than the others. It was perceived that they were threatening the very foundations of the European welfare states. Such was the statement of the UK Home Secretary in 2004 that despite positive effects of migration from the new member states, accession nationals were welcome to the UK only to work but not to claim benefits. A further intention was to restrict benefit entitlement (Roberts 2015).

Yet a study by the European Commission on this subject found little evidence of "benefit tourism" in Europe and contradicted claims by the governments in the UK, Germany, Austria and the Netherlands that EU social security systems were under strain, especially from Romanian and Bulgarian migrants (ICF GHK 2013). The study further showed that non-active EU migrants made up a very small share of the total population in each Member State. Also, on average, EU migrants were more likely to be employed than nationals living in the same country. Finally, the study showed that the vast majority of non-active EU migrants (79\%) lived in economically active households, with only a minority of them living with other household members out of work (ICF GHK 2013).

In relation to the issue of supposed "welfare tourism" in the new EU Member States, Kmak (2015) found that the European Commission puts a strong emphasis on the work-oriented mobility of EU citizens and on the improvement of their personal lives, as well as reinvigoration of the EU economy. This assumption, in her view, suggested that EU citizens were subjectivised as "economic men", rational and mobile individuals willing to travel to other countries in order to find remuneration best reflecting their skills. It is worth mentioning that the Commission's emphasis on the significant prevalence of work-orientated mobility was followed by the information that only a small number of mobile EU citizens were economically inactive. Kmak (2015: 400) observed that "the Commission perceives EU citizens not only as rational

6 Directive 2004/58/EC of the the European Parliament and of the Council of 29 April 2004 on the right of citizens of the Union and their family members to move and reside freely within the territory of the Member States amending Regulation (EEC) No 1612/68 and repealing Directives 64/221/EEC, 68/360/EEC, 72/194/EEC, 73/148/EEC, 75/34/EEC, 75/35/EEC, 90/364/ EEC,90/365/EEC and 93/96/EEC (Official Journal of the European Union L 158 of 30 April 2004). 
but also as moral individuals, whose mobility is guided by work rather than the wish to be idle and to benefit from social assistance of receiving states". A similar message is conveyed through the talk about lifestyle, amenity and/or retirement migrants who are welcome only conditionally - when possessing sufficient economic means for living (Dwyer, Papadimitrou 2004).

Finally, Lafleur and Mescoli (2018: 481) believe that "with the economic and financial crisis, welfare policies are increasingly being turned into instruments for limiting the mobility of EU migrants". They further argue that restrictions to the "mobility of the poor" are mirrored in debates about migration selectivity, grounded in the perceived economic contribution of both non-EU as well as EU migrants. However, in these debates, not only the economic worth of individual migrants, but also ethnicised notions about the proper composition of national populations, come to the forefront.

\section{Ethnicity Matters in Labour Mobility}

The utilitaristic stance that migrants are needed to fill up labour shortages in selected sectors seems problematic in several ways. Gill (2009) demonstrated that the exploitation of migrants as a labour force that would fill up sectoral deficiencies in "native" labour markets without enabling them access to an array of social, economic and political rights was one of the perils of a conservative approach to the policy of unlimited migration. In this sense, the author also saw the attitude of proponents of the policy of open borders that the economic benefits of increased migration outweighed its costs as problematic. In an effort to disprove the argument that migrants would take away citizens' jobs, decrease their wage levels and/or overburden the national welfare systems, Gill noted the danger of entering into the discussion of "worth" and "legitimate" migration (ibid.). The same applies to programmes for managing migration/mobility, limiting/enabling access to the labour markets, favourable treatment for admission, and programmes designed to match labour supply with demand (Kyrieri 2007), which are a standard element of most nation-states' migration/mobility policies. Policies and discussions that recognise the "value" of mobile/ migrant workers for the respective national economies also seem to convey the message that certain "kinds" of migrants are more valuable than others. There is a discrepancy between the desirable "migrant elites" and the migrant labour force that is perceived as needed by the policymakers and the general public (Zavratnik 2011).

The utilitarian understanding of migration is usually amplified with "arguments" about cultural differences and similarities that supposedly affect the possibility and level of migrant integration into a society. The chances of foreigners being allowed to play a role in a given society are seen as higher when they are perceived as being "easy to integrate". As Fox et al. (2012) showed in their analysis of the media in the UK, when covering the migration of East Europeans (particularly Hungarians and 
Romanians) into the UK, the media invoked cultural difference as the basis for exclusion, and constructed cultural traits as a basis for differentiation. The authors found that the "Roma frame" in the media was freely applied to individuals who would not necessarily define themselves as Roma, in particular Romanians. In government policy discourses, on the other hand, "assumptions about shared whiteness operate as implicit criteria for racialized inclusion: East Europeans are desirable because they conform to the racialized understandings of Europeanness" (ibid.: 691).

In this view, Favell (2008) insisted that East European migrants from "new" Member States were increasingly filling the jobs considered as 3D (dirty, dangerous and dull) due to their perceived ethnic "similarity" and cultural "proximity" in comparison to the previously preferred "non-white" and "non-European" people. Favell also argued that an internal and regional labour market was increasingly developing. On the other hand, l'affaire des Roms, in which almost 1,000 Romanian and Bulgarian nationals of Roma origin living in France were expelled from the country in 2010 due to their supposed inability to sustain themselves economically and their "criminality" (Carrera, Faure Atger 2010; Lafleur, Mescoli 2018) remains a pertinent example of undermining the notion of free movement within the EU and of the ethnicisation of the Roma as "illegitimate" mobile individuals.

\section{CONCLUDING REMARKS}

The current European picture of parallel trends of large-scale international migration, below-replacement fertility and ageing population is a demographic reality which as a rule stirs up fears and concerns of a vanishing European civilisation. The neglected field of the intertwined relationship between politics and population changes is often filled with rhetoric of exaggeration and garbled interpretations by politicians and journalists, who usually misunderstand and misuse demographic calculations and long-term population projections, or manipulate them in line with their political interests (Teitelbaum 2004, 2015).

However, such fears are also embedded in the demographic reasoning of empirically-based evidence of membership of nation-state population units, which as a rule serves as a guide for population policymakers. Neglecting questions of who or what is counted how, when and in what circumstances they are counted and how collective identities are defined renders demographic reasoning in line with the anachronistic idea of a national population as a closed system with a "proper composition", where "the prime consideration is once again not the number of people but their 'quality'"' (Melegh 2006: 72)

Such primordial notions about the proper composition of the national populations are also continuously present in the discussions about movement of people within the EU borders. Intra-European movement, as observed by Van Ostaijen (2016), was classified by the European Commission as mobility and not as migration 
due to the historical construction of the $\mathrm{EU}$ as a single or internal market. Despite the EU's commitment to the free movement of people as a means of further European integration, various mechanisms, such as transitional restrictions of entry to the EU labour markets, sectoral quotas, programmes to match labour supply with demand, the conditioning of residence upon the principle of sufficient economic means and the limiting of welfare state assistance to economically inactive individuals, curtail the free movement of individuals across the EU. Furthermore, in these discussions, cultural traits are constructed as a basis for differentiation and social exclusion of particular social groups. Therefore, it is not surprising that Lafleur and Mescoli (2018) even prefer to use the terms "EU migrants" over "mobile EU citizens" to reflect the precariousness of their status, which many individuals from EU countries share with third country nationals.

Whether and how to reconcile the apparently contradictory ideology of free movement within the EU, the "need for" migrants in ageing and low-fertility EU societies and the still prevailing demographic reasoning about the maintenance of a "proper composition of the population" remains a challenge for scientific reasoning beyond the closed system of national populations.

\section{REFERENCES}

Barslund, Mikkel, Busse, Matthias (2016). Labour Mobility in the EU Addressing challenges and ensuring 'fair mobility'. Brussels: CEPS, https://www.ceps.eu/system/ files/SR139\%20MB\%20and\%20MB\%20LabourMobility.pdf (15. 10. 2017).

Carrera, Sergio, Faure Atger, Anaïs (2010). L'affaire des Roms: A Challenge to the EU's Area of Freedom, Security and Justice. Brussels: Centre for European Policy Studies, https://www.ceps.eu/system/files/book/2010/09/Carrera\%20\%26\%20Faure\%20 Atger\%20on\%20Roma\%20Affair.pdf (15. 7. 2018).

CEPS (2014). Making the Most of EU Labour Mobility. Brussels: Centre for European Policy Studies, https://www.ceps.eu/system/files/CEPS\%20Making\%20the\%20 Most\%20of\%20Labour\%20Mobility\%200ct-3.pdf (10. 5. 2018).

Coleman, David (2006). Immigration and Ethnic Change in Low-Fertility Countries: A Third Demographic Transition. Population and Development Review 32/3, 401-446.

Coleman, David, Basten, Stuart, Billari C. Francesco (2015). Population-The Long View. Population Studies: A Journal of Demography 69/S1, S1-S9.

Ciupijus, Zinovijus (2011). Mobile Central Eastern Europeans in Britain: Successful European Union Citizens and Disadvantaged Labour Migrants? Work, Employment and Society 25/3, 540-550.

Demeny, Paul (1988). Social Science and Population Policy. Population and Development Review 14/3, 451-479.

Directive 2004/58/EC of the European Parliament and of the Council of 29 April 2004 on the Right of Citizens of the Union and their Family Members to Move and 
Reside Freely within the Territory of the Member States Amending Regulation (EEC) No 1612/68 and Repealing Directives 64/221/EEC, 68/360/EEC, 72/194/EEC, 73/148/EEC, 75/34/EEC, 75/35/EEC, 90/364/EEC,90/365/EEC and 93/96/EEC (Official Journal of the European Union L 158 of 30 April 2004), https://eur-lex.europa. eu/LexUriServ/LexUriServ.do?uri=OJ:L:2004:229:0035:0048:en:PDF (10. 7. 2018).

Douglass, Carrie B. (ed.) (2005). Barren states: The Population 'Implosion' in Europe. Oxford, New York: Berg.

Dwyer, Peter, Papadimitriou, Dimitris (2006). The Social Security Rights of Older International Migrants in the European Union. Journal of Ethnic and Migration Studies 32/8, 1301-1319.

ECF GHK (2013). A Fact Finding Analysis on the Impact on the Member States' Social Security Systems of the Entitlements of Non-active Intra-EU Migrants to Special Non-contributory Cash Benefits and Healthcare Granted on the Basis of Residence, http://ec.europa.eu/employment_social/empl_portal/facebook/20131014\%20 GHK\%20study\%20web_EU\%20migration.pdf (10.11. 2017).

EUROFOUND (2014). Labour Mobility in the EU: Recent Trends and Policies. Luxembourg: Publications Offices of the European Union.

European Commission (2013). Communication from the Commission to the European Parliament, the Council, the European Economic and Social Committee and the Committee of the Regions. Free Movement of EU Citizens and their Families: Five Actions to Make a Difference. Brussels, https://eur-lex.europa.eu/legal-content/EN/ TXT/PDF/?uri=CELEX:52013DC0837\&from=EN (15. 11. 2017)

Favell, Adrian (2008). The New Face of the East-West Migration in Europe. Journal of Ethnic and Migration Studies 34/5, 701-716.

Fox, Jon E., Moroşanu, Laura, Szilassy, Eszter (2012). Racialization of the New European Migration to the UK. Sociology 46/4, 680-695.

Friedlander, Dov, Okun, Barbara S., Segal, Sharon (1999). The Demographic Transition Then and Now: Processes, Perspectives, and Analyses. Journal of Family History 24/4, 493-533.

Gill, Nick (2009). Whose "No Borders" Achieving Border Liberalization for the Right Reasons. Refuge 26/2, 107-120.

Goldstone, Jack A. (2012). A Theory of political Demography: Human and Institutional Reproduction, Political Demography: How Population Changes Are Reshaping International Security and National Politics (eds. Jack A. Goldstone, Eric P. Kaufmann, Monica Duffy Toft). Boulder, London: Paradigm Publishers, 10-28.

Hodgson, Dennis (1991). The Ideological Origins of the Population Association of America. Population and Development Review 17/1, 1-34.

Kertzer, David I., Fricke, Tom (eds.) (1997). Anthropological Demography: Toward a New Synthesis. Chicago, London: The University of Chicago Press.

Kertzer, David I., Fricke, Tom (eds.) (1997). Toward an Anthropological Demography. Anthropological Demography: Toward a New Synthesis. Chicago, London: The University of Chicago Press, 1-35. 
Kligman, Gail (2005). A Reflection on Barren States: The Demographic Paradoxes of Consumer Capitalism. Barren states: The Population 'Implosion' in Europe (ed. Carrie B. Douglass). Oxford, New York: Berg, 249-259.

Kmak, Magdalena (2015). Between Citizen and Bogus Asylum Seeker: Management of Migration in the EU through Technology of Morality. Social Identities 21/4, 395-409.

Kreager, Philip (1993). Histories of Demography. Population Studies 47/3, 519-539.

Kreager, Philip (1997). Population and Identity: Anthropological Demography. Anthropological Demography: Toward a New Synthesis (eds. David Kertzer, Tom Fricke). Chicago, London: The University of Chicago Press, 139-174.

Kreager, Philip (2008). Aristotle and Open Population Thinking. Population and Development Review 34/4: 599-629.

Kreager, Philip (2009). Darwin and Lotka: Two Concepts of Population. Demographic Research 21/16: 469-502.

Kreager, Philip (2015). Population theory - A long View. Population Studies: A Journal of Demography 69/S1: S29-S37.

Kyrieri, Katerina Marina (2007). Demographic Changes, Immigration Policy and Development in the European Union. EIPASCOPE 2, 21-26.

Lafleur, Michel, Mescoli, Elisa (2018). Creating Undocumented EU Migrants through Welfare: A Conceptualization of Undeserving and Precarious Citizenship. Sociology 52/3, 480-496.

Melegh, Attila (2006). On the East-West Slope: Globalization, Nationalism, Racism and Discourses on Eastern Europe. New York: Central European University Press, http:// www.pwsz.krosno.pl/gfx/pwszkrosno/pl/defaultaktualnosci/675/5/1/s06_ab_ attila_melegh_eastwest.pdf. (29. 10.2017).

Pijpers, Roos (2007). Between Fear of Masses and Freedom of Movement: Migrant Flexwork in the Enlarged European Union. PhD thesis. Nijmegen: Department of Human Geography and Spatial Planning, Radboud University.

Pijpers, Roos (2009). International Employment Agencies and Migrant Flexiwork in an Enlarged European Union. Journal of Ethnic and Migration Studies 36/7, 10791097.

Roberts, Simon (2015). Benefit Tourism: A Moral Panic? Maltese Seminar: 'Benefit Tourism: Myth or Reality' 27 May 2015, http://ec.europa.eu/social/BlobServlet?do$\mathrm{cld}=14044 \&$ langld $=$ en (23. 11. 2017).

Szreter, Simon (1993). The Idea of Demographic Transition and the Study of Fertility Change: A Critical Intellectual History. Population and Development Review 19/4, 659-702.

Teitelbaum, Michael S., Winter, Jay (1998). A Question of Numbers: High Migration, Low Fertility, and the Politics of National Identity. New York: Hill and Wang.

Teitelbaum, Michael S. (2004). The Media Marketplace for Garbled Demography. Population and Development Review 30/2, 317-327. 
Teitelbaum, Michael S. (2015). Political Demography: Powerful Trends Under-Attended by Demographic Science. Population Studies: A Journal of Demography 69/S1, S87-S95.

Treaty on the Functioning of the European Union (2012). Official Journal of the European Union 326/47.

Van de Kaa, Dirk Jan (1987). Europe's Second Demographic Transition. Population Bulletin 42/1, 3-57.

Van de Kaa, Dirk Jan (1999). Europe and its Population: The Long View. European Populations: Unity in Diversity (eds. Dirk Jan van de Kaa, Henri Leridon, Giuseppe Gesano, Marek Okólski). Dordrecht, Boston, London: Kluwer Academic Publishers, $1-50$.

Van De Kaa, Dirk Jan (2002). The Idea of a Second Demographic Transition in Industrialized Countries. Paper presented at the sixth Welfare Policy Seminar of the National Institute of Population and Social Security, Tokyo, Japan, 29 January, http:// www.ipss.go.jp/webj-ad/WebJournal.files/population/2003_4/Kaa.pdf (10. 3. 2017).

Vah Jevšnik, Mojca, Rogelja, Nataša (2018). Occupational Safety and Health in Transnational Workplaces: The Case of Posted Workers. Dve Domovini / Two Homelands $48,23-36$.

Van Houtum, Henk, Van Der Velde, Martin (2004). The Power of Cross-border Labour Market Immobility. Tijdschrift voor Economische en Sociale Geografie 95/1, 100-107.

Van Ostaijen, Mark (2016). Between Migration and Mobility Discourses: The Performative Potential within 'Intra-European Movement'. Critical Policy Studies 11/2, $1-25$.

Weiner, Myron, Teitelbaum, Michael, S. (2001). Political Demography, Demographic Engineering. New York, Oxford: Berghahn Books.

Zavratnik, Simona (2011). Sodobne migracije v mnenjih slovenske javnosti. Dve domovini / Two Homelands 33, 55-71. 


\section{POVZETEK}

\section{DELOVNA MOBILNOST IN MIGRACIJE V VPRAŠLJIVEM DEMOGRAFSKEM UMOVANJU Duška KNEŽEVIĆ HOČEVAR, Sanja CUKUT KRILIĆ}

Besedilo ponuja pregled vprašljivega demografskega umovanja migracij in mobilnosti, ki še vedno vztraja pri ideji nacionalnega prebivalstva kot zaprtega in zamejenega sistema s »primerno sestavo« svojega prebivalstva. Nedavni zaskrbljeni in neusklajeni odzivi evropskih vlad na »begunsko krizo« in obsežne migracije v starajočo se Evropo so ponovno oživili demografske distopične predstave o reproduktivno bolj vitalnih tujcih oziroma v tujini rojenih ljudeh, ki domnevno ogrožajo obstoječe vrednote, način življenja, družbeni položaj in celo kulturo manj reproduktivnega domačega prebivalstva. To problematiko besedilo sprva presoja s predstavitvijo poskusov preučevanja političnih posledic tovrstnih prebivalstvenih gibanj, da bi se potrdilo ali ovrglo strahove in zaskrbljenosti glede spremenjene prebivalstvene sestave. Za boljše razumevanje nastalih demografskih distopij besedilo naslavlja središčni demografski koncept (nacionalnega) prebivalstva in zgodovino njegovega oblikovanja.

V nadaljevanju besedilo presoja tovrstne demografske predstave, ki implicitno naslavljajo in zajemajo tudi mobilne posameznike in posameznice ter delovne migrante in migrantke, ki jih uradne statistike praviloma označujejo kot v tujini rojene ljudi ali jih kot kratkoročno priseljene posameznike in posameznice $v$ statističnem štetju nacionalnega prebivalstva sploh ne registrirajo. Čeprav je svobodno gibanje ljudi med temeljnimi načeli Evropske unije, avtorici zatrjujeta, da je njihova mobilnost v njej selektivna in na različne načine omejena. Na podlagi izbranih raziskav delovne mobilnosti in delovnih migracij v Evropski uniji avtorici potrjujeta, da delovne mobilnosti in migracije politike nadzirajo in upravljajo s pomočjo mehanizmov, ki ljudi še naprej razporejajo kot bolj ali manj upravičene do gibanja čez meje nacionalnih držav Evropske unije. Med mehanizmi vzdrževanja želene družbenoekonomske sestave prebivalstva avtorici presojata prehodne omejitve vstopa na trge dela držav članic, sektorske kvote, programe za usklajevanje ponudbe na trgu dela z njegovimi potrebami, pogojevanje pravice do bivanja z zadostnimi ekonomskimi sredstvi in omejevanje pomoči države blaginje ekonomsko neaktivnim ljudem. Obenem pokažeta, da ti mehanizmi naslavljajo tudi bolj ali manj podobne ali oddaljene kulturne značilnosti priseljencev in priseljenk kot podlago za razlikovanje in družbeno izključevanje določenih družbenih skupin. Ali in kako uskladiti protislovje med ideologijo prostega gibanja ljudi v Evropski uniji, »potrebo po« migrantih in migrantkah v starajočih družbah s prevladujočimi trendi nizke rodnosti ter še vedno prevladujočim demografskim umovanjem o vzdrževanju »primerne prebivalstvene sestave«, ostajata dilema in izziv za znanstveni pogled onkraj zaprtega sistema nacionalnega prebivalstva. 